\title{
ASSESSMENT OF THE NATIVE HABITATS OF PANTHERA TIGRIS AND IDENTIFICATION OF SUITABLE SITES FOR CAPTIVE BREEDING OF THIS SPECIES IN TAMIL NADU USING GIS
}

\author{
Nambi Manavalan Rajan \\ K. Ramakrishnan College Of Technology, Trichy, India
}

\begin{abstract}
The Bengal tiger (with zoological name: Panthera tigris) is the largest among all cat species. The number of mature tigers living in earth is in-between 2,154 to 3,159 individuals and its current population trend is decreasing since its population is severely fragmented. Its major threats come from anthropogenic disturbances, urbanization and lack of sufficient neighbouring animals like deer, bovids, etc. If the tiger population faces threats within their native habitats, ex-situ conservatory measures could be adopted by Governmental agencies to ensure captive breeding in the newly established tiger habitats outside its own. The Study Area of this research is Tamil Nadu, India. In this research has assessed the native habitats of Panthera tigris in Tamil Nadu in terms of its ecological prosperity and also has identified the suitable sites for the establishment of captive breeding sites, for Panthera tigris, in Tamil Nadu. As the final result, a site in Theni district, with an area of $183.04 \mathrm{~km} 2$, has been identified (using 'weighted average' method) as the proposed site for the ex-situ conservation of this animal species in Tamil Nadu. The software used in this research is ArcGIS 10.4.
\end{abstract}

Keywords: Panthera tigris, Captive Breeding of Species

Cite this Article: Nambi Manavalan Rajan, Assessment of the Native Habitats of Panthera Tigris and Identification of Suitable Sites for Captive Breeding of this Species in Tamil Nadu Using Gis, International Journal of Advanced Research in Engineering and Technology, 10(1), 2019, pp. 136-153.

http://iaeme.com/Home/issue/IJARET?Volume=10\&Issue $=1$

\section{INTRODUCTION}

A tiger can easily be recognized with its pattern of dark vertical stripes on reddish-orange fur with a lighter underside. This species is classified in the genus Panthera along with lion, leopard, jaguar, snow leopard, etc. It is an apex predator, chiefly preying on ungulates such as bovids and deer.

The Bengal tiger (with zoological name: Panthera tigris) is the largest among all cat species. Its habitat features grassland, shrubland and thick forests. It is territorial and generally a solitary but social predator, often requiring large contiguous areas of habitat 
that support its prey requirements. Tiger is also the national animal of India, Bangladesh, Malaysia and South Korea. Tigers are found mainly in the forests of tropical Asia, although they historically occurred more widely in drier and colder climes. Availability of a sufficient prey base of large ungulates is the Tiger's major habitat requirement: "wild pigs and deer of various species are the two prey types that make up the bulk of the Tiger's diet, and in general Tigers require a good population of these species in order to survive and reproduce" (Hayward et al. 2012, Sunquist and Sunquist 2002). Tigers need to kill 50-60 large prey animals per year (Karanth et al. 2004, Miller et al. 2013). Tigers are opportunistic predators, however, and their diet includes birds, fish, rodents, insects, amphibians, reptiles in addition to other mammals such as primates and porcupines. Tigers can also take ungulate prey much larger than themselves, including large bovids (Water Buffalo, Gaur, Banteng), elephants and rhinos (Nowell and Jackson 1996). However, like many large carnivores, preferred prey is key to successful reproduction and are those species that are approximately the same weight as Tigers themselves (Hayward et al. 2012).

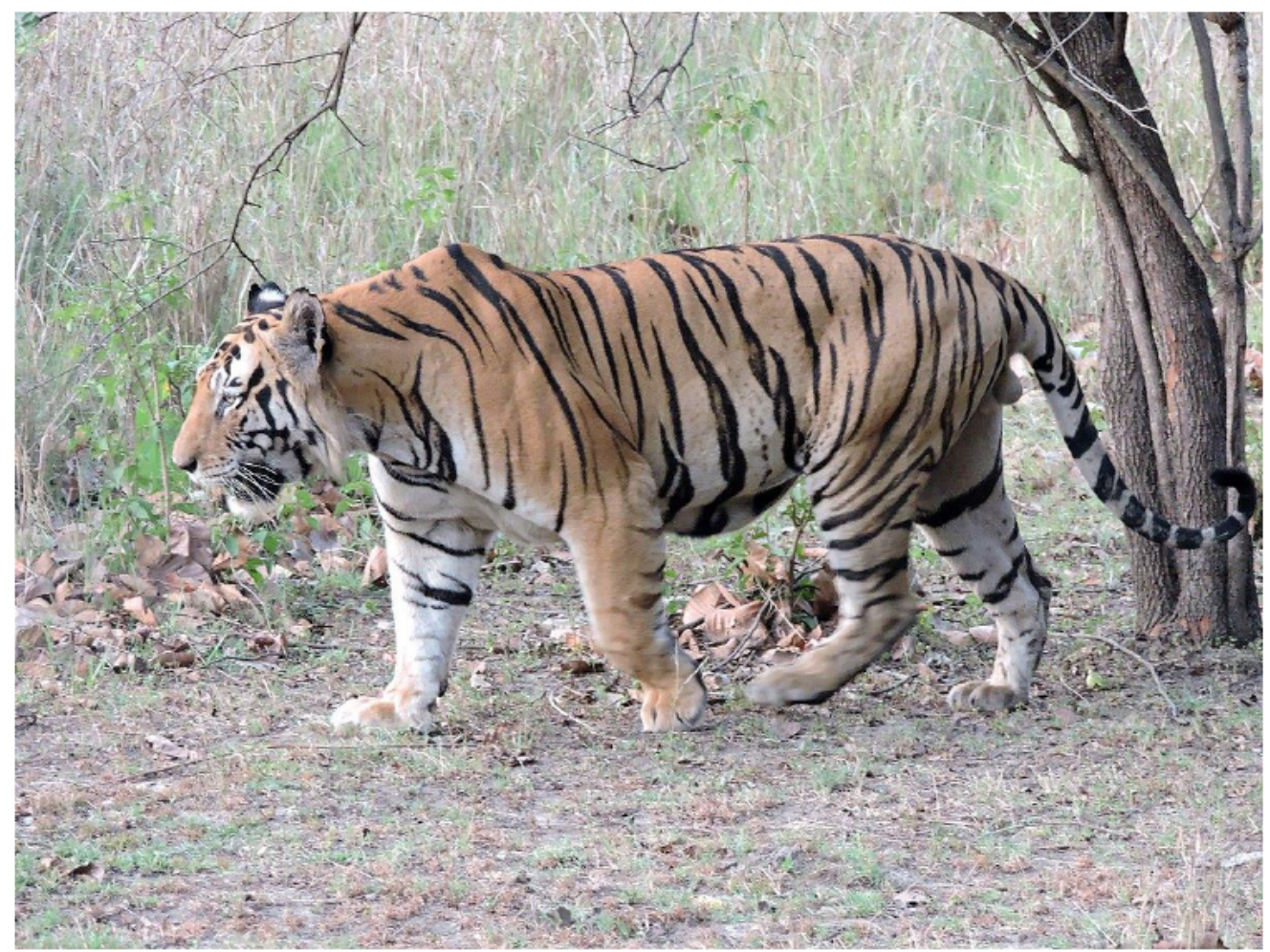

Kingdom-Animalia

Phylum-Chordata

Class-Mammalia

Order-Carnivora

Family-Felidae

Genus-Panthera

Species-Panthera tigris 


\section{THREATS TO TIGER}

Poaching is the number one threat to the tiger's existence. The prevalence of this threat will have a major bearing on whether or not the species goes extinct in many important landscapes. Every single tiger organ is sold on the black market today. Tiger parts are used for traditional medicines thought to cure ailments ranging from arthritis to epilepsy, with the greatest demand in China. Tiger skins and other parts are also used for décor, indicating status and wealth, across Asia.

The tiger is increasingly under threat from deforestation for agricultural developments, especially monocultures like palm oil plantations. As a result, the species now remains in only around $4 \%$ of its historic range.

Habitat loss and overhunting by humans also depletes populations of tiger prey, like deer and wild pigs, forcing tigers to attack livestock to feed themselves and their cubs. Inevitably, this fuels human-tiger conflict, in which villagers take retaliatory measures to protect their herds and communities.

Wild tigers are hunted to meet the demands of the $\$ 20$ billion in a year within the illegal wildlife market. Tiger parts are consumed for traditional medicinal purposes across Asia, with a heavy demand in China. Wild tigers are persecuted when villagers take retaliatory measures to protect their livestock and communities. Tiger habitat is increasingly under threat from agricultural developments, especially monocultures like palm oil plantations. Tiger prey, like deer and wild pigs, continue to be overhunted, forcing tigers to attack livestock to feed themselves and their cubs, thus fuelling human-tiger conflict.

Just over a century ago, there were as many as 100,000 wild tigers living in Asia. Today, fewer than 3,900 remain. The tiger is classified into nine subspecies, three of which (Javan, Caspian, and Bali) are extinct. A fourth, the South-China subspecies is most likely extinct in the wild, with no signs of its existence in the last decade. The existing subspecies are Bengal, Indochinese, Sumatran, Siberian, and Malayan. Tigers are globally listed as "Endangered" on the International Union for the Conservation of Nature (IUCN) Red List of Threatened Species.

The number of mature tigers living in earth is in-between 2,154 to 3,159 individuals and its current population trend is decreasing since its population is severely fragmented. Its major threats come from anthropogenic disturbances, urbanization and lack of sufficient neighbouring animals like deer, bovids, etc. If the tiger population faces threats within their native habitats, ex-situ conservatory measures could be adopted by the Governmental agencies to ensure captive breeding in the newly established tiger habitats outside its own.

\section{SAVING THE TIGER}

'Panthera's Tigers Forever program' is working at key sites in Bangladesh, India, Indonesia, Malaysia, Nepal, and Thailand with the aim of increasing tiger numbers at each site by at least 50 percent over a ten-year period. Helmed by Panthera's Tiger Task Force, the Tigers Forever program focuses on addressing the most serious threats to tigers, which include direct killing, depletion of prey, and habitat loss and fragmentation. Panthera's activities include combatting poaching and other illegal activities through implementing effective enforcement of protected areas through well-trained park guards, identifying and securing tiger habitats, and using cutting-edge camera technology to prevent poaching and to protect and monitor tiger and prey populations.

\section{STUDY AREA}

The Study Area of this research is Tamil Nadu (a state in India), the location of which is depicted in Figure 1. Figure 1 also shows the map of Tamil Nadu with its districts. It is the 
eleventh largest state in India with an area of 1,30,394.39 km2. It is also the sixth-most populous Indian state with a population of 7,21,47,030 people. Tamil is the official language of this study area. About $80.33 \%$ of the people are literate. The Density of Population in this study area is 550 persons per km2 (Source: www.tn.gov.in) and it has 32 districts.

It is geographically positioned between the latitudes $8^{\circ} 5^{\prime} 0^{\prime \prime} \mathrm{N}$ and $13^{\circ} 35^{\prime} 0$ " $\mathrm{N}$, and the longitudes $76^{\circ} 15^{\prime} 0^{\prime \prime} \mathrm{E}$ and $80^{\circ} 20^{\prime} 0^{\prime \prime} \mathrm{E}$. It is one of the 29 Indian states, with Chennai as its capital, which is also the largest city in Tamil Nadu.

Tamil Nadu lies in the southernmost portion of the Indian Peninsula sharing the border with Puducherry, Andhra Pradesh, Karnataka, and Kerala. It is enclosed by Anamalai hills, Nilgiri hills and Kerala in the west, Bay of Bengal in the east, Eastern Ghats in the north, Indian Ocean in the south, and Palk Strait and Gulf of Mannar in the southeast. The Country of Sri Lanka shares a maritime boundary with Tamil Nadu.

Coastal plains, present in the eastern parts of Tamil Nadu, are very fertile in nature. The Northern portions are composed of a combination of plains and hills. The Plains of the study area occupy more than half of the state's area. Arid plains, which get comparatively less precipitation, are present in the central and the south central parts of Tamil Nadu. Tamil Nadu's coastline is the second lengthiest $(1,076 \mathrm{~km})$ in India (Source: www.tn.gov.in).

The Study area has a forest area spread of $18,182 \mathrm{~km}^{2}$ (Figure 2). This contributes to about $13.94 \%$ and $2.95 \%$ of the state's geographical area and India's forest area respectively. 


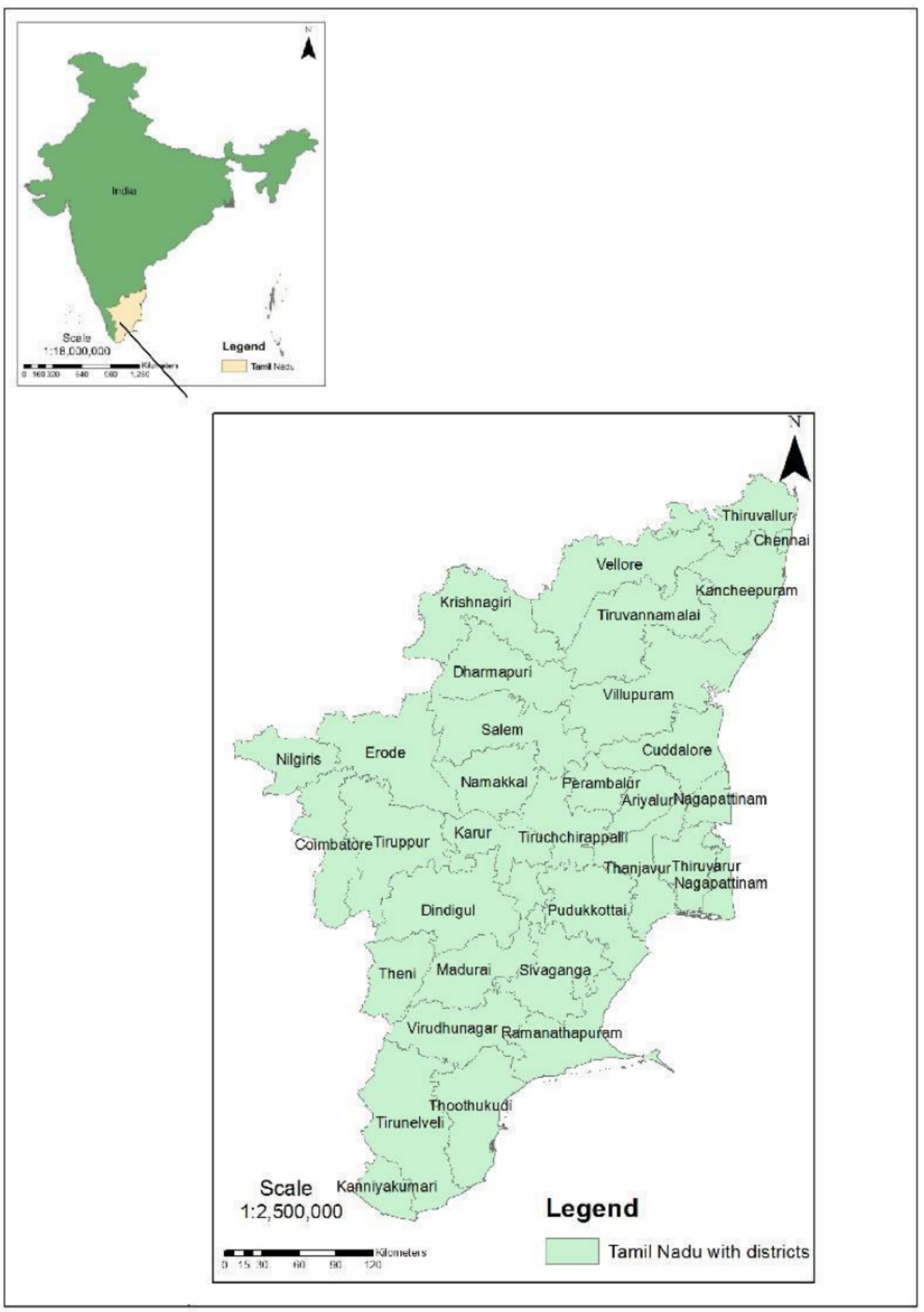

Figure 1 Map showing the study-area 


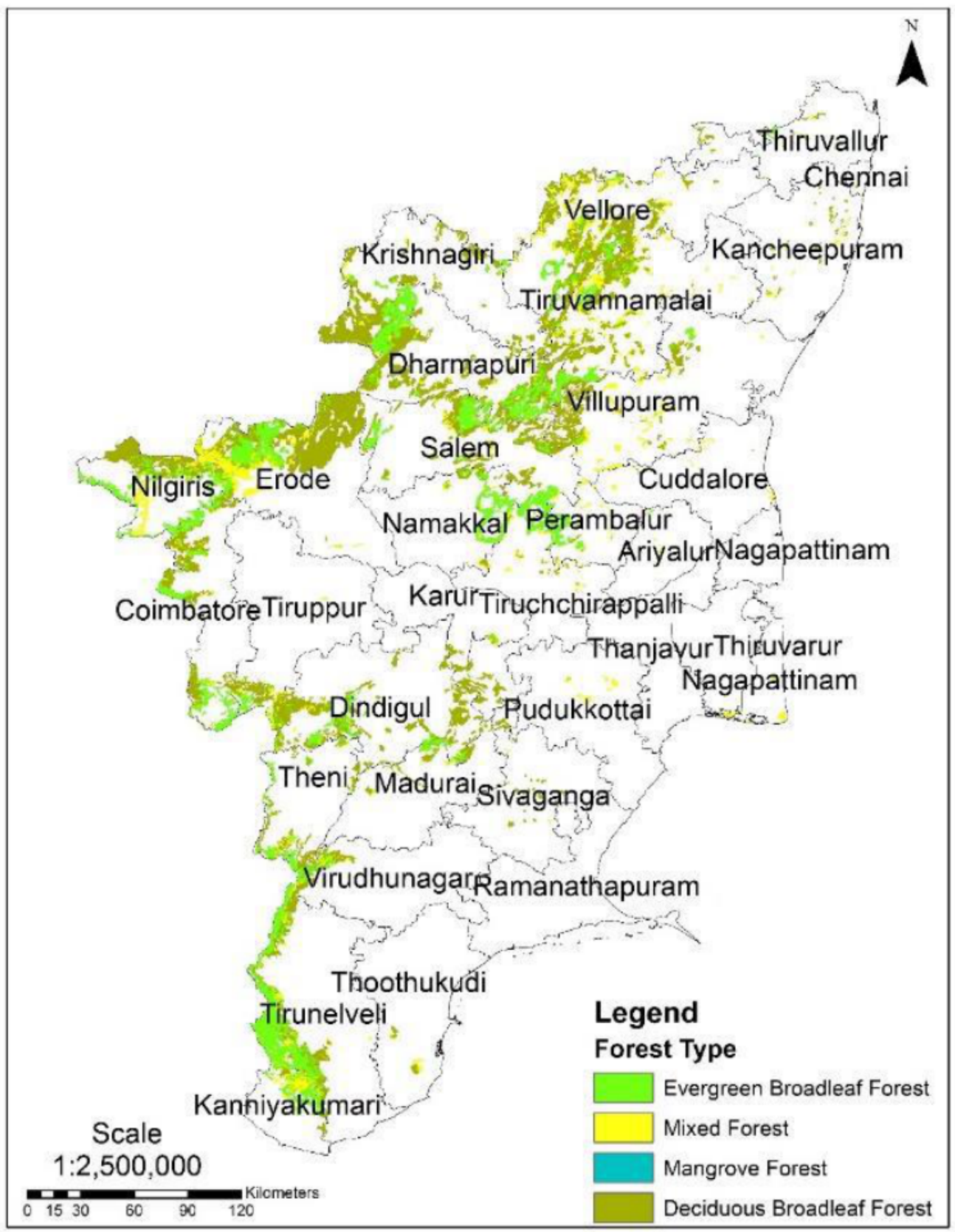

Figure 2 Forest cover map of Tamil Nadu

\section{METHODOLOGY}

This research has two major objectives as follows:

i. To assess the native habitats of Panthera tigris in Tamil Nadu in terms of its ecological prosperity,

ii. To identify the suitable sites for the establishment of captive breeding sites, for Panthera tigris, in Tamil Nadu.

Assessment of the tiger's native habitats involves the mapping of the different degrees of ecological prosperities in their spatial extents in Tamil Nadu. The degree of ecological prosperity of an area has been projected as a map output by referring to it as 'Decreased 
Ecological-Prosperity Index' ( DEPI ). In this research, the range of DEPI values is taken as 0 to 6. The DEPI value had been assigned to each pixel depending on the factors such as,

- preponderance of other terrestrial mammals in that area,

- its proximity to water bodies like lakes and rivers, and

- its distance from human settlements and from all types of roads.

So, for finding the DEPI value of a pixel, the processing is involved with all the three factors' relatedsteps. These processes have been discussed factor-wise in-detail as follows:

\section{PREPONDERANCE OF OTHER TERRESTRIAL MAMMALS}

The Spatial range data (in .shp format) i.e. the actual locational information of all terrestrial mammals have been downloaded from the website of 'IUCN Red list of Threatened species', the weblink of which is 'https: // www.iucnredlist.org/resources/spatial-data-download'. This shapefile consists the locational information of about 12,968 terrestrial mammals in the world. From this data, the spatial extents of Panthera tigris in Tamil Nadu (the study-area) have alone been extracted using the 'Clip' tool available in ArcGIS 10.4 software package. It has been found that within these native habitats of Panthera tigris, a number of 41 terrestrial mammals (Table 1) do survive and exist predominantly, which can be preyed by the tiger species. The vector files of terrestrial mammals other than Panthera tigris within its native habitats are converted into raster image formats with each pixel having a cell value of ' 1 '. Now these assorted rastersare clubbed to form a single raster image using the mosaicking operation named as 'SUM'. So, this operation ensures that the raster cell value of a pixel is the 'summed up' value of all the overly in grasters. This means that in a particular region any number of terrestrial mammals could exist. Such scenarios give enough prosperity for the survival of the tiger species in those areas. The final map has been prepared which indicates the regions of lesserpreponderances, of terrestrial mammals, with low DEPI value for Panthera tigris and viceversa. The DEPI value (with respect to preponderance of other terrestrial mammals alone) for all areas, within the tiger's native habitat boundaries, have been assigned using the inverseproportionality concept. So, as the number of observed presences of many mammals in an area increase, the DEPI value decreases. 
Assessment of the Native Habitats of Panthera Tigris and Identification of Suitable Sites for Captive Breeding of this Species in Tamil Nadu Using Gis

Table 1

\begin{tabular}{|c|c|c|c|}
\hline $\begin{array}{l}\text { SI. } \\
\text { No. }\end{array}$ & Species Name & $\begin{array}{l}\text { SI. } \\
\text { No. }\end{array}$ & Species Name \\
\hline 1 & Prionailurusbengalensis & 22 & Anathanaellioti \\
\hline 2 & Suncusetruscus & 23 & Mus musculus \\
\hline 3 & Mus saxicola & 24 & Paradoxurus hermaphroditus \\
\hline 4 & Mus phillipsi & 25 & Manis crassicaudata \\
\hline 5 & Madromysblanfordi & 26 & Rattus rattus \\
\hline 6 & Vandeleuria oleracea & 27 & Tateraindica \\
\hline 7 & Hyaena hyaena & 28 & Mellivoracapensis \\
\hline 8 & Canis lupus & 29 & Muntiacus vaginalis \\
\hline 9 & Golundaellioti & 30 & Mus terricolor \\
\hline 10 & Macaca radiata & 31 & Bandicotabengalensis \\
\hline 11 & Sus scrofa & 32 & Prionailurusrubiginosus \\
\hline 12 & Hystrixindica & 33 & Viverriculaindica \\
\hline 13 & Rusa unicolor & 34 & Vulpes bengalensis \\
\hline 14 & Herpestessmithii & 35 & Antilope cervicapra \\
\hline 15 & Felischaus & 36 & Herpestesedwardsii \\
\hline 16 & Funambuluspalmarum & 37 & Lepus nigricollis \\
\hline 17 & Suncusmurinus & 38 & Boselaphustragocamelus \\
\hline 18 & Bandicotaindica & 39 & Millardiameltada \\
\hline 19 & Axis axis & 40 & Mus booduga \\
\hline 20 & Moschiolaindica & 41 & Semnopithecusdussumieri \\
\hline 21 & Canis aureus & & \\
\hline
\end{tabular}

\subsection{Proximity to water bodies}

Using the 'Quick-Bird' satellite images available in ArcGIS Online platform (http://goto.arcgisonline.com/maps/World_Imagery), the water bodies present within the tiger's native habitats of Tamil Nadu have been vectorized and used for the proximity analysis. A 'zero-valued' raster image, of tiger's native habitats, is taken and then, each pixel's 'Euclidean distance' from the digitized water bodies is computed. With reference to Naha et. al., 2016, it has been known that, usually Panthera tigris move upto a maximum of $4.6 \mathrm{~km}$ per day. Thus, keeping this distance into account, raster cells having values greater than $4.6 \mathrm{~km}$ are ignored and are assigned with 'zero' DEPI, while the rest of them are computed for their DEPI values using the direct-proportionality concept. So, as the distance of a pixel from water bodies increases, DEPI value also increases. 


\subsection{Anthropogenic risk analysis}

Anthropogenic risks include disturbances from humans such as hunting, residential \& commercial development, energy production \& mining activities, recreational activities, and natural system modifications. In order to assess these risks in Tamil Nadu, the concerned Road and Settlement shapefiles have been created, by the vectorization of the same using the 'Google Earth Pro' software (http:// www.earth.google.com ). Then, the Euclidean distances are calculated to all the pixels within the tiger's native habitats. This operation is done using 'Euclidean Distance' tool present in 'Spatial Analyst' toolbox of ArcGIS 10.4. This tool calculates the distances in meters from all the cells to the nearest features (i.e roads or settlements).Anthropogenic risks for the survival of Panthera tigrisget aggravated as the distances of tiger presences to roads and human settlements decreases. Using this inverseproportionality concept, suitable anthropogenic risk indices are assigned to all pixels based on these distances. The areas that are within $1500 \mathrm{~m}$ (from roads) and $2000 \mathrm{~m}$ (from settlements) are alone assigned with risk indices. The Areas that are beyond these distances are assigned with 'zero' anthropogenic risk indices.

Now, all the three raster layers pertaining to the three factors discussed above, are overlaid such that all pixels get the average value of 3 raster layers. Hence, the final DEPI value map has been obtained.

\subsection{Site Suitability Analysis for ex-situ conservation}

Identifying suitable sites for ex-situ conservation through captive breeding, in other areas of Tamil Nadu, formed the second primary objective in this research. As the first step, forest areas in Tamil Nadu have alone been filtered, for to be considered for site selection. The forest areas have been extracted using land-use / land-cover maps from www.openstreetmaps.org. In the second step, the filtered forest areas have been further narrowed down to the ones that are completely free from any kind of anthropogenic threats (i.e. with zero risk index). Then, the preponderance of other mammals in the updated filtered areas is assessed and each pixel has been assigned with a value which has been measured as the 'Ecological Prosperity Index' (EPI). Higher the number of mammals in an area, higher is the EPI value that has been assigned to the same and vice-versa. Analysis of all the areas in Tamil Nadu for their respective proximity to water bodies formed the next step in this research. Thus, keeping the distance of $4.6 \mathrm{~km}$ into account, raster cells having values greater than $4.6 \mathrm{~km}$ are ignored and are assigned with 'zero' EPI, while the rest of them are computed for their EPI values using the inverse-proportionality concept. So, as the distance of a pixel from water bodies increases, EPI value decreases. In the next step, all the raster layers prepared have been overlaid and averaged with the EPI values for each layer. Now, the boundaries of the native habitats of the Bengal tiger have been subtracted to show the areas that are suitable for ex-situ conservation in the other areas of Tamil Nadu. Hence, the final EPI map is prepared, thus satisfying the second primary objective of this research.

\section{RESULTS AND DISCUSSION}

The native habitats (which is related to the well-known ranging activities) of Panthera tigrisarespread across a total area of $6,577.72 \mathrm{~km}^{2}$. 
Assessment of the Native Habitats of Panthera Tigris and Identification of Suitable Sites for Captive Breeding of this Species in Tamil Nadu Using Gis

Table 2 Tiger's native habitat landscape area extents in various districts

\begin{tabular}{|c|c|}
\hline DISTRICT & $\begin{array}{c}\text { HABITAT AREA } \\
\text { EXTENT (in km }{ }^{2} \text { ) }\end{array}$ \\
\hline Erode & 2032.26 \\
\hline Coimbatore & 1204.36 \\
\hline Tirunelveli & 1150.76 \\
\hline Nilgiris & 913.87 \\
\hline Theni & 508.23 \\
\hline Dindigul & 272.96 \\
\hline Virudhunagar & 249.28 \\
\hline Madurai & 200.86 \\
\hline Kanyakumari & 23.77 \\
\hline Salem & 21.33 \\
\hline
\end{tabular}

As per this table, Erode district has the largest area with the widest known ranging activities of Panthera tigris. The Sathyamangalam forest of Erode district and the Anamalai hills of Coimbatore district, act as safe havens for this species. The wider distribution of human settlements and rapid urbanization in the Salem district restrict the Bengal tiger to have its native habitat limited within an area of $21.33 \mathrm{~km}^{2}$.

Also, when the preponderance of mammals other than Panthera tigris is considered, the Sathyamangalam forest of Erode district comes first due to which this species is found to be in large numbers when compared to in other districts. This means that this species finds it easy to prey upon these mammals for its survival.

When the figure 3 is analysed it comes to be known that the tiger's native habitats in the Nilgiris district are most affected due to anthropogenic threats for the survival of Panthera tigris. This effect is due to the rapid urbanization in the same.

When Figure 3 is noticed it is evident that some areas of the Tiger habitats in the Coimbatore district face slightly higher threats when compared to with the other districts. This is because of the presence of water bodies, like lakes and rivers, at greater distances from the tiger habitats. This issue is largely not present in the Tirunelveli district due to presence of nearby water resources therein.

Figure 4 shows the 'Ecological Prosperity Index' (EPI) map of Tamil Nadu with respect to the presence of mammals other than the Bengal tiger in Tamil Nadu. It is known from overlay analysis that Nilgiris district tops with the greatest number of mammals (i.e. 60) that Tiger can prey upon for its survival in Tamil Nadu. But from Figure 5 it is inferred that Nilgiris district has higher anthropogenic threats making it to sustain a consolidated safer area extent of just $196.97 \mathrm{~km}^{2}$ (Table 3), which also has a comparatively lesser number of mammals, present therein (Figure 4).Figure 5(b) shows the areas in Tamil Nadu that are safer from anthropogenic threats due to access from roads and settlements. The Total area, of this extent in Tamil Nadu, is found to be $4230.94 \mathrm{~km}^{2}$. The Identified Safer regions are present in 24 districts of Tamil Nadu.Tirunelveli is the district with the greatest safer region extent with an area of $903.88 \mathrm{~km}^{2}$ (Table 3), while Perambalur is the district with the smallest safer region extent with an area of $1.24 \mathrm{~km}^{2}$. This implies that Perambalur district is highly unsafe in terms of anthropogenic 
threats likely to be posed to Panthera tigris during its ex-situ conservation therein. But since Tirunelveli district has the largest safer area extent it can be considered for establishing a new site for this animal's ex-situ conservation. This could be the most likely reason for this place's preference as the site for ex-situ conservation herein, bearing the name 'KalakkadMundanthurai Tiger Reserve'.

It can also be seen from Figure 4 that, as we have a look from the coastal areas to the Western Ghats, the areas with the frequently sighted number of mammals subsequently decrease. This is because of the progressively reducing ecological prosperity, from coastal regions to the Western Ghats, with respect to climate, vegetation and land-use.

Table 3 shows the district-wise area covered by the identified safer regions in Tamil Nadu. Table 4 shows the district-wise area of forests in Tamil Nadu. Figure 5 shows the Tamil Nadu Map that highlights the areas that are, within forest boundaries, safer from anthropogenic threats, and that have greater access to water bodies. Table 5 shows the district-wise area of boundaries that are, within forests, safer from anthropogenic threats, and that have greater access to water bodies. Table 5 shows that Tirunelveli district ranks third in terms of districtwise areas within forests, and within the reach for water bodies (especially). Whereas, a site (Figure 6) in Theni district (with an area of $183.04 \mathrm{~km}^{2}$ ) has got all the required Ecological prosperities and has the most favourable place that could satisfy all the required and necessary conditions, for the successful captive breeding of the Bengal tiger.

It may also be noted that, though Krishnagiri district is seen with better other mammals presences, its areas have not been shown in Figure 5(d) as a suitable area for the proposed tiger reserve. This is because of the fact that, these respective areas are found to have very lesser extents of safer areas from anthropogenic threats, with an area of $68.84 \mathrm{~km}^{2}$ (Table 3).

Also, though Coimbatore district has good safer area extent of $262.26 \mathrm{~km}^{2}$ (Table 3), it has not been preferred as the proposed site because it has not got water bodies (like lakes and streams) within the reach of Panthera tigris, if shifted thereto. This case is similar with respect to Erode district too (Figure 5(c)).

Figure 6 shows the 'GeoEye' satellite's image of the proposed Ex-situ conservation area in Theni district acquired on 30/04/2017. Figure 6 shows that the proposed site is significantly free from anthropogenic threats, as there are no roads and settlements found within its limits. Figure 3 shows that the South-Western regions of Dindigul district (which are also just present nearer to the proposed ex-situ conservation site in Theni district), bears the native tiger habitats. From Figure 3 it can be implied that these respective regions are found to be at risk, for the survival of the Bengal species, due to its least proximity to the water body presences, and also, it is found with lesser preponderance of other mammal species. So, the Bengal tigers from its habitats in these regions or from any-other similar tiger reserves, can suitably be shifted to the proposed ex-situ conservation site, in the Northern parts of Theni district, for their most-likely successful captive breeding. 
Assessment of the Native Habitats of Panthera Tigris and Identification of Suitable Sites for Captive Breeding of this Species in Tamil Nadu Using Gis

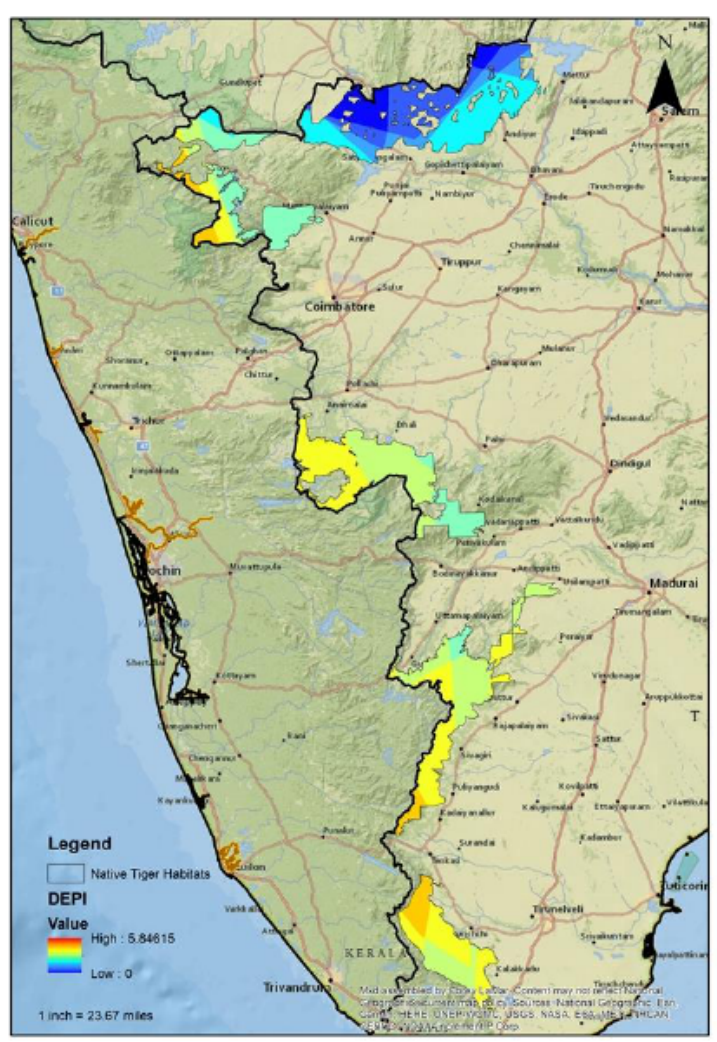

(i) DEPI Map w.r.t preponderance of other mammals

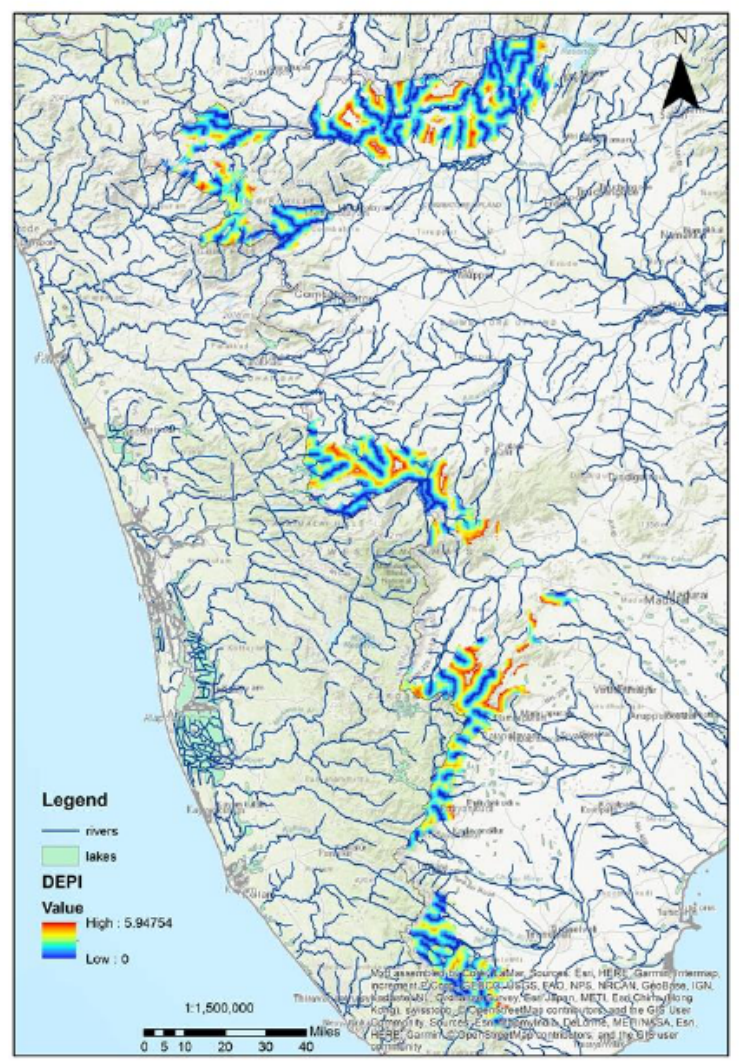

(iii) DEPI Map w.r.t proximity from water bodies

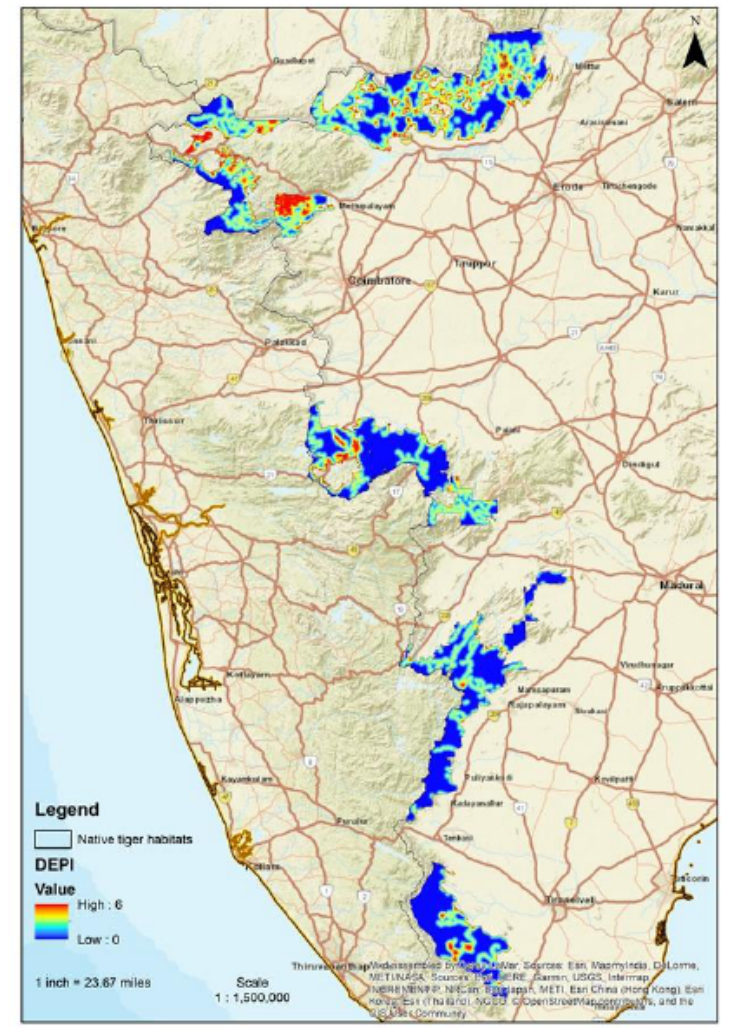

(ii) DEPI Map w.r.t anthropogenic threats

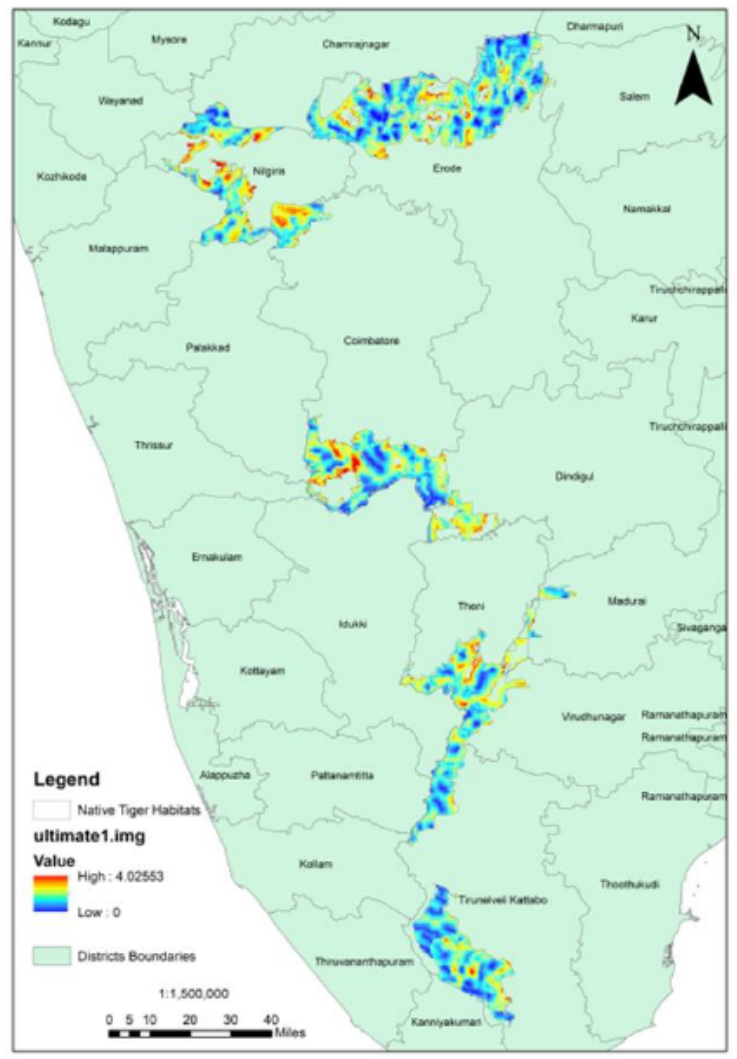

(iv) DEPI Map w.r.t all factors

Figure 3 DEPI Maps with respect to each factor and all factors combined 


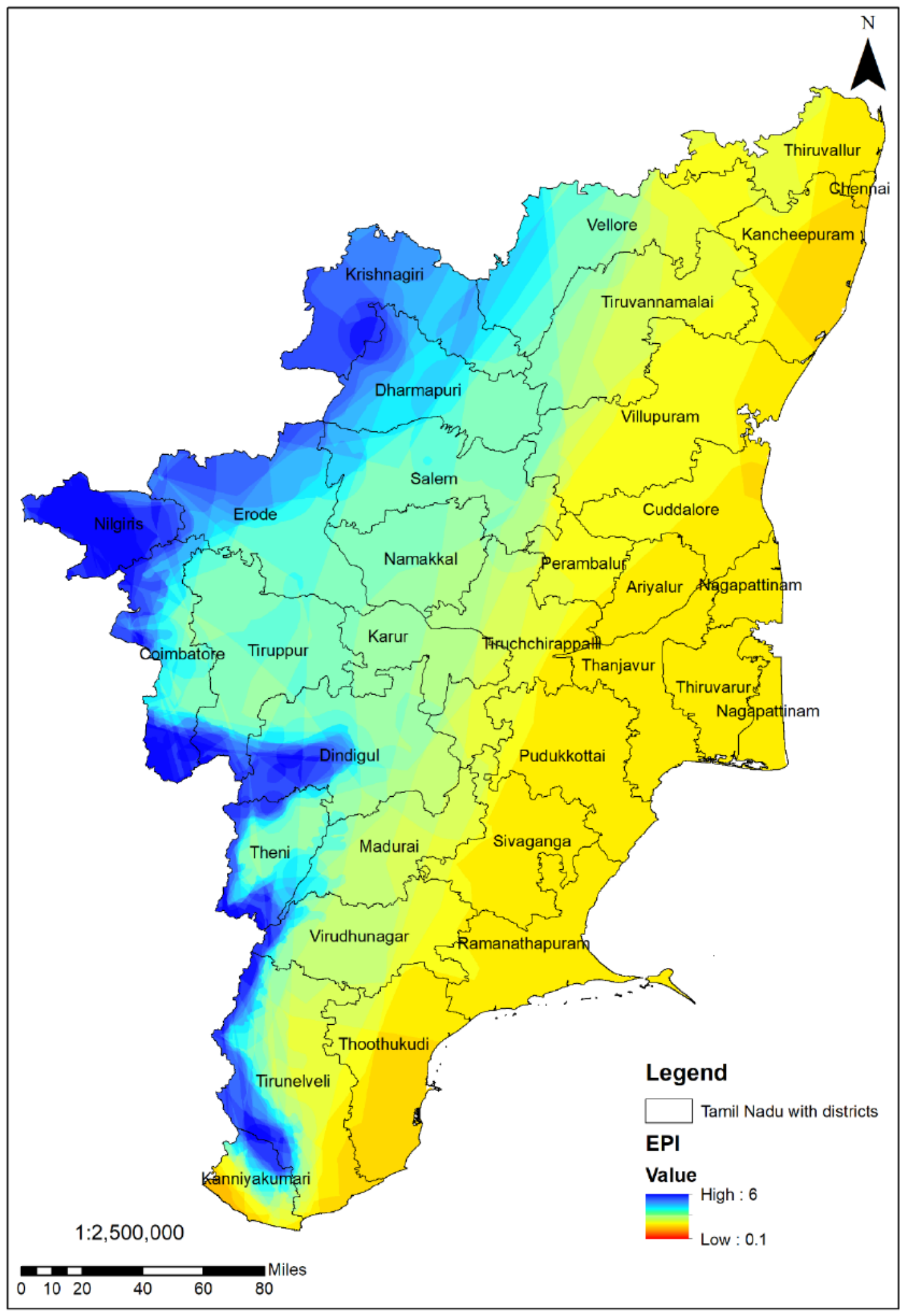

Figure 4 Ecological Prosperity Index (EPI) map of Tamil Nadu with respect to other mammals presence 
Assessment of the Native Habitats of Panthera Tigris and Identification of Suitable Sites for Captive Breeding of this Species in Tamil Nadu Using Gis

Table 3 Area covered by the identified safer regions in the districts of Tamil Nadu

\begin{tabular}{|c|c|c|c|}
\hline District Name & $\begin{array}{c}\text { Area covered by the } \\
\text { identified safer regions in } \\
\text { each district (in } \mathbf{~ k m}^{\mathbf{2}} \text { ) }\end{array}$ & District Name & $\begin{array}{c}\text { Area covered by the } \\
\text { identified safer regions in } \\
\text { each district (in km²) }\end{array}$ \\
\hline Tirunelveli & 903.88 & Vellore & 92.97 \\
\hline Theni & 532.46 & Thiruvarur & 87.92 \\
\hline Erode & 425.41 & Krishnagiri & 68.84 \\
\hline Dindigul & 346.68 & Villupuram & 63.07 \\
\hline Tiruppur & 291.52 & Salem & 36.79 \\
\hline Coimbatore & 262.26 & Namakkal & 26.78 \\
\hline Madurai & 239.00 & Thoothukudi & 21.69 \\
\hline Dharmapuri & 212.67 & Thiruvallur & 20.28 \\
\hline Nilgiris & 196.97 & Karur & 15.08 \\
\hline Tiruvannamalai & 132.90 & Thanjavur & 11.64 \\
\hline Kanniyakumari & 122.58 & Tiruchchirappalli & 7.39 \\
\hline Virudhunagar & 110.92 & Perambalur & 1.24 \\
\hline
\end{tabular}

Table 4 District-wise area of forests in Tamil Nadu

\begin{tabular}{|c|c|c|c|}
\hline District & Forest area (in $\mathbf{k m}^{\mathbf{2}}$ ) & District & Forest area (in $\mathbf{k m}^{\mathbf{2}}$ ) \\
\hline Ariyalur & 15.75 & Perambalur & 205.36 \\
\hline Chennai & 3.47 & Pudukkottai & 56.73 \\
\hline Coimbatore & 998.26 & Salem & 1308.10 \\
\hline Cuddalore & 47.70 & Sivagangai & 87.48 \\
\hline Dharmapuri & 1537.80 & Theni & 428.09 \\
\hline Dindigul & 1038.10 & Thiruvallur & 95.84 \\
\hline Erode & 2236.14 & Thiruvarur & 22.41 \\
\hline Kanchipuram & 116.44 & Thoothukudi & 57.53 \\
\hline Kanniyakumari & 368.92 & Tiruchirappalli & 434.01 \\
\hline Karur & 73.97 & Tirunelveli & 1391.37 \\
\hline Krishnagiri & 1274.22 & Tiruppur & 390.34 \\
\hline Madurai & 188.06 & Tiruvannamalai & 1481.41 \\
\hline Nagapattinam & 29.21 & Vellore & 1672.06 \\
\hline Namakkal & 385.40 & Vilupuram & 849.75 \\
\hline Nilgiris & 1108.82 & Virudhunagar & 279.16 \\
\hline
\end{tabular}

(Source: www.forests.tn.nic.in) 

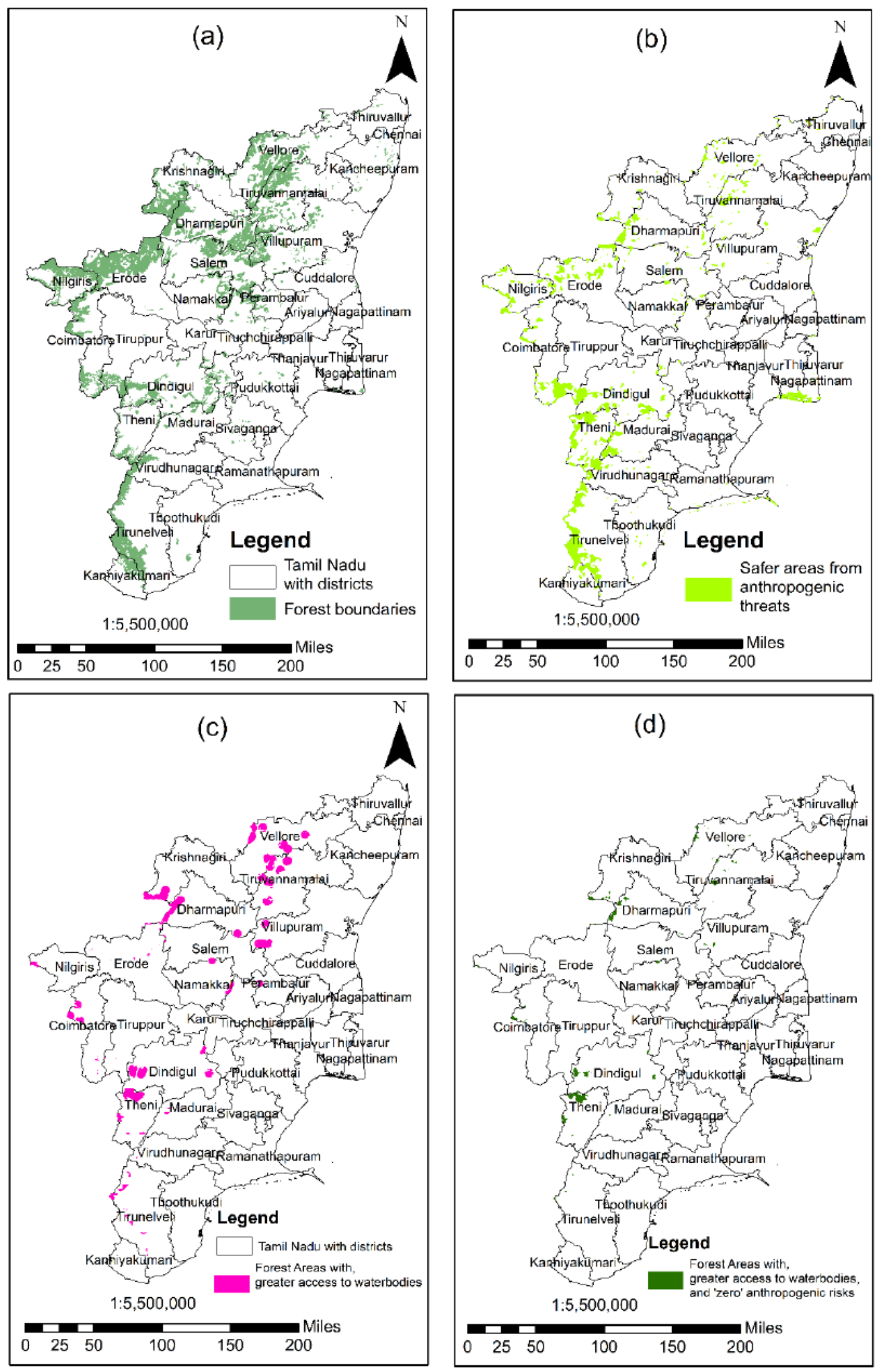

Figure 5 Tamil Nadu Map highlighting the areas that are, within forest boundaries, safer from anthropogenic threats, and that have greater access to water bodies 
Assessment of the Native Habitats of Panthera Tigris and Identification of Suitable Sites for Captive Breeding of this Species in Tamil Nadu Using Gis

Table 5 District-wise area of boundaries that are, within forests, safer from anthropogenic threats, and that have greater access to water bodies

\begin{tabular}{|c|c|c|c|}
\hline DISTRICT NAME & AREA (in sq. km) & DISTRICT NAME & AREA (in sq. km) \\
\hline THENI & 183.04 & TIRUNELVELI & 11.11 \\
\hline DHARMAPURI & 100.44 & NILGIRIS & 6.59 \\
\hline DINDIGUL & 98.91 & ERODE & 6.11 \\
\hline TIRUVANNAMALAI & 59.40 & KARUR & 5.37 \\
\hline VELLORE & 50.58 & MADURAI & 1.48 \\
\hline KRISHNAGIRI & 47.55 & PERAMBALUR & 1.23 \\
\hline COIMBATORE & 30.80 & SALEM & 1.16 \\
\hline VILLUPURAM & 20.46 & TIRUCHIRAPPALLI & 0.36 \\
\hline NAMAKKAL & 16.28 & TIRUPPUR & 0.11 \\
\hline
\end{tabular}




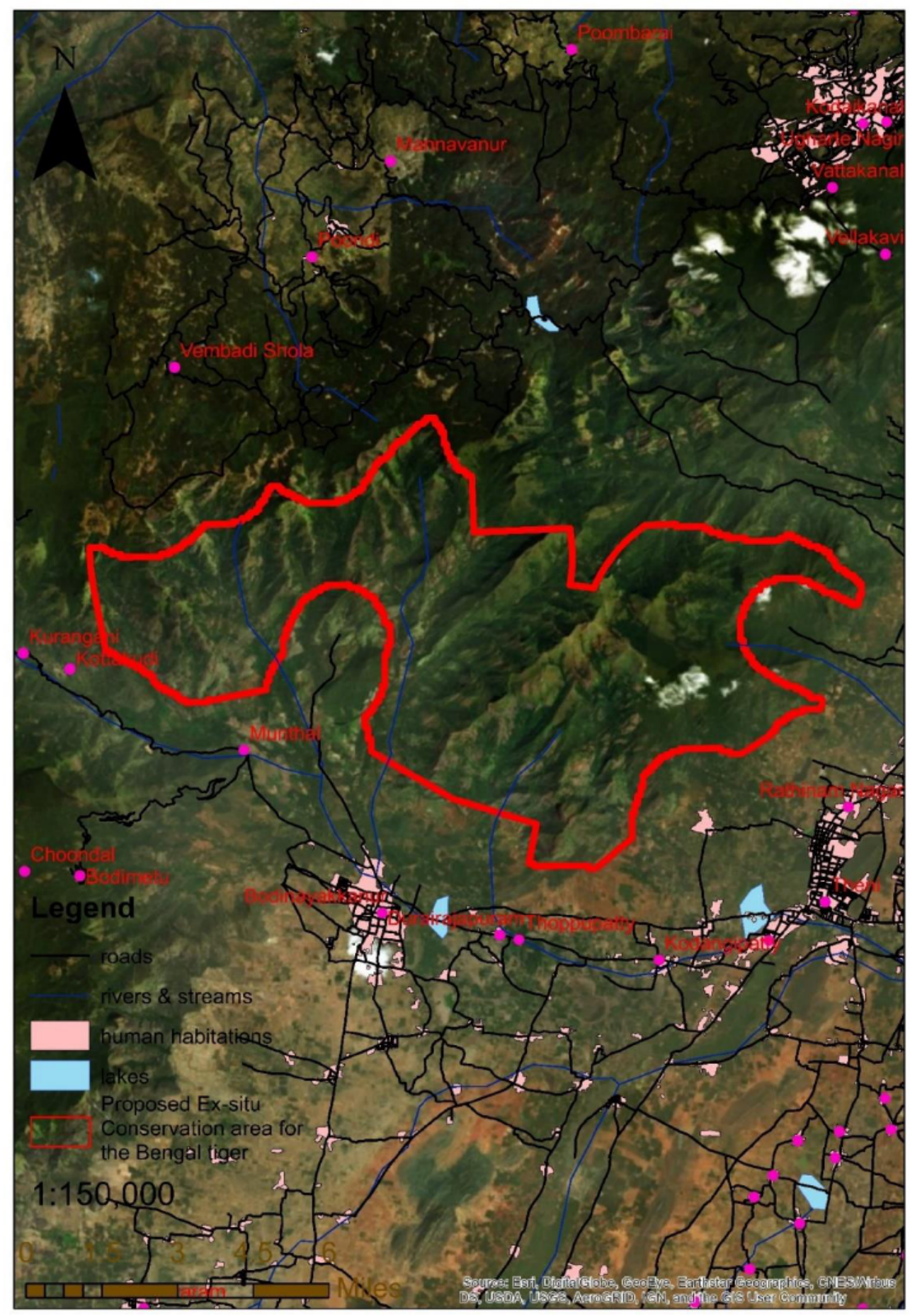

Figure 6 GeoEye satellite image of the proposed Ex-situ conservation area in Theni district acquired on $30 / 04 / 2017$

\section{CONCLUSION}

The areas in Table 4 are processed mathematically, to find out the area with the highest 'weighted average' which is the product of 'mean' of all pixel values (which are present in the intersecting areas of Figure 4 and Figure 5(d) alone), and 'area' of the individual boundaries. As a result, it comes to be known that the area shown in Figure 6 (with an area of $183.04 \mathrm{~km}^{2}$ ) 
Assessment of the Native Habitats of Panthera Tigris and Identification of Suitable Sites for Captive Breeding of this Species in Tamil Nadu Using Gis

has the highest weighted average making it the proposed site for the captive breeding of this animal species. Thus, if this particular area is properly fenced, there could be lesser chances for human beings to have their interferences towards the insides of the proposed ex-situ conservation of Panthera tigris, herein. Thus, in this research, this site in Theni district (Figure 6) has been identified to be the most ideal site in Tamil Nadu, in terms of anthropogenic threats, prosperity of all the required ecological needs, for the safe and health survival of Panthera tigris, such as drinking water and preferable mammals upon which this Bengal tiger can prey.

\section{REFERENCES}

[1] Hayward, MW , Jedrzejewski, W, Jedrzejewska, B (2012), 'Prey preferences of the tiger Panthera tigris', Journal of Zoology; 286 (3), pp 221-231.

[2] Sunquist, M, Sunquist, F (2004), 'Wild Cats of the World', Journal of Mammalogy, 85 (2), pp 365-366.

[3] Abulkhaleq Kamal Mahmood and Reham Riyadh Mahmoud, Study and Evaluation of Noise Pollution in Kut Technical Institute Using Gis System, International Journal of Civil Engineering and Technology, 9(11), 2018, pp. 1573-1584.

[4] Karanth, KU, Nichols, JD, Kumar, NS, Link, WA, Hines, JE (2004), 'Tigers and their prey: Predicting carnivore densities from prey abundance', Proceedings of the National Academy of Sciences of the United States of America; 101 (14), pp 4854-4858.

[5] Miller, CS, Hebblewhite, M, Petrunenko, YK, Seryodkin, IV, DeCesare, NJ, Goodrich, JM, Miquelle, DG (2013), 'Estimating Amur tiger (Panthera tigrisaltaica) kill rates and potential consumption rates using global positioning system collars', Journal of Mammalogy, 94 (4), pp 845-855.

[6] Kadhim Naief Kadhim and Ahmed Awad Matr Al-Abody. The Geotechnical Maps for Bearing Capacity by Using GIS and Quality of Ground Water for Al-Imam District (Babil - Iraq). International Journal of Civil Engineering and Technology, 6(10), 2015, pp. 176-184.

[7] Nowell K, Jackson P. (1996), North Africa and Southwest Asia, Cheetah. In: Nowell K, Jackson P, editors. Wild cats: Status survey and conservation action plan. Gland, Switzerland: IUCN/SSC Cat Specialist Group; p 41-44.

[8] Tamil Nadu Forest Department. 2016, Available from : $<$ http://www. forests.tn.nic.in $>$ [31 Jan 2019].

[9] Tamil Nadu. 2016, Available from : $<$ http://www.tn.gov. in/ tamilnadustate $>$ [31 Jan 2019].

[10] 8. Openstreetmaps. 2018, Available from: $<$ https://planet.openstreetmap.org $>$ [05 Dec 2018].

[11] Kadhim Naief Kadhim and Ghufran Ahmed Jwad Al-Baaj, The Geotechnical Maps for Gypsum by Using GIS For Najaf City (Najaf - Iraq). International Journal of Civil Engineering and Technology, 7(4), 2016, pp.329-338.

[12] IUCN Red list. 2018, Available from: <https://www.iucnredlist.org/resources/spatialdata-download $>$ [05 Dec 2018].

[13] ArcGIS Online: World Imagery. 2018, Available from: $<$ http://goto.arcgisonline.com/maps/World_Imagery $>$ [05 Dec 2018].

[14] Google earth Pro V 7.3.2.5491. (December 14, 2015). Tamil Nadu, India. 110737.64 N, 783924.82 E, Eye alt 1172.07 km. SIO, NOAA, U.S. Navy, NGA, GEBCO. TerraMetrics 2018, GigitalGlobe 2018. Available from: $<$ http://www.earth.google.com> [05 Dec 2018]. 